"This paper has been accepted for publication in Pastoral Care in Education, and the final (edited, revised and typeset) version will be published Vol. 26, No. 1, March 2008, 5-11 (C) Routledge”

\title{
Depoliticisation, demoralisation and depersonalisation - and how to better them
}

\author{
Chris Watkins
}

Institute of Education, University of London, London, UK

\begin{abstract}
An important contribution to the thinking behind this paper came during a recent discussion of government policies called 'personalisation'. When asked 'what is the problem to which personalized learning is a solution?', one delegate at a deputy heads' conference replied 'depersonalised learning'. This simple but powerful point struck a chord and helped me to think further about the way that trends in recent decades have downgraded the focus on human qualities in the field formerly known as education.
\end{abstract}

For this reflection I have chosen three aspects: the political, the moral, and the personal. There could be more - perhaps it is time to coin the word 'desocialisation' to describe the way that consideration of social qualities and social processes can be downgraded.

\section{Depoliticisation}

Dynamics associated with power, authority, organisation and governance has always characterised life in classrooms. This has been analysed as the micropolitics of the classroom since the 1940s. Then the rise of fascism had highlighted major challenges to democracies, and such politics informed what could be illuminated in classroom life (Lewin, Lippitt, \& White, 1939). In this 'micro' sense, none of us as teachers can escape politics in our everyday practice. On a wider scale, the dynamics of politics in a society have also been a focus in education. In decades past, political education, although not always a timetabled subject, had a clear focus and supportive resources to match (Stradling, 1981). It was supported by official statements on the curriculum (Department of Education and Science, 1978). But by 1988 the journal Teaching Politics was renamed Talking Politics.

I take education necessarily to have a political dimension, whether this is explicitly recognised or not. But nowadays the elements briefly mentioned in the previous paragraph receive little explicit attention. The power balance in classrooms is not mentioned in current orthodoxy, where more and more teacher-directed methods are recommended by government and its agents. The term 'political education' is very rarely used nowadays, and its concerns have not been incorporated into the more individualised provision, 'citizenship'. This latter seems more driven by politicians' fears of 'the democratic deficit' and the use of existing political structures, than by questions of how we think the world should be and of enhancing political agency (McCowan, 2006). More recently, the dynamics of globalisation have led citizenship to become the means whereby foreigners learn English 'values', rather than a provision for addressing the discrimination and marginalisation experienced by certain groups in society.

But then, the politics of education have changed, especially in the last 20 years, so that increasing prescription from central government and less exercise of independence at local authority level mean a different culture for teachers and schools. For teachers today, these politics are different from the ones experienced by previous generations (Gardner, 1998). Such a change was forecast in the early part of the last century by thinkers in the Frankfurt school, and followed up by their second generation, especially Habermas. They foresaw that as it became clearer that national governments have little impact on 
international economics in late capitalism, they would direct their claims for potency to the domestic sphere. Hence, education has been subjected to a major increase in administrative planning by the state. With the example of curriculum planning, Habermas notes how this process grows: 'Administrative planning produces a universal pressure for legitimation in a sphere that was once distinguished precisely for its power of selflegitimation' (1975, p. 71).

On this wider note, in the late 1980s, it became fashionable to argue that "capitalism has won', but this is too easy an argument based on a simple polarisation with socialism. It forgets two more important issues on which the recent evidence is pressing: economic richness does not necessarily lead to a better quality of life or to happier children, and current versions of capitalism compromise sustainability for the planet.

Demoralisation

Teaching is a moral enterprise, but that does not mean that it spends its time moralising, but rather that it cannot escape conveying messages of who and what are deemed good or valuable. At a wider level, too, the whole process of education includes many elements which value some priorities over others - which knowledge is seen as good, which people deserve resources, and so on.

Here again, I take the moral dimension to be inescapable, whether or not this is explicitly recognised in the system. But nowadays the considerations of this moral dimension have been sidelined. Instead the orthodoxies, especially those promulgated by government, substitute the functionalist approach ('what works?') and a consumerist approach (what do customers, parents, governors or employers want?) for the more complex discussion of what is best. Moral education is rarely discussed despite there being evidence that education can bring together disparate stances into a cohering set of purposes and values (School Curriculum and Assessment Authority, 1996).

It is ironic that, in a world context where a variety of fundamentalisms clash, the processes which can bridge such divides and build communication are de-emphasised in schooling, and the way in which 'faith schools' are justified in consumerist terms runs the risk of elevating individual choice to state policy.

Demoralisation also affects the teaching profession, as it is treated to mechanical and functionalist views of school and schooling. When mechanical forms of 'management' were being imposed on our schools, I remember some committed colleagues saying, 'You can't talk with teachers about morale any more: it's a morass'. Thus, the moral commitment of the teaching profession - to make a difference in young people's lives - became less talked about. But the evidence remains: the factors which led teachers to join the profession (working with children or young people, and a creative challenging role) are the same factors which inform why they stay, whereas the factors which demotivate them most are workload, initiative overload, and the targetdriven culture (General Teaching Council for England, 2003).

\section{Depersonalisation}

To suggest that people in education are seen less as persons would appear nonsensical, but the point is that they are treated that way. As recent statements on 'personalisation' in public services have recognised, policies to date have resulted in 'public services seeming more machine-like, more like a production line producing standardised goods' (Leadbeater, 2004 , p. 81). This situation has been generated by a number of forces. The rhetoric of 'standards' in education soon slides into standardisation (McLaughlin, 1991). Thus, we get a 'one size fits all' mentality rather than one size fits few (Ohanian, 1999). Increased amounts of curriculum specification affect classroom pedagogy in such a way that it reverts to a 'delivery' model (e.g. Jenkins, 2000), with a dominant focus on what teachers do instead of on the variety of what learners do. Under these conditions, the range of identities available to pupils is severely limited, to the point that one 11-year-old says, 'So I'm frightened I'll do the SATS and I'll be a nothing' (Reay \& Wiliam, 1999, p. 345). 
For teachers, too, the process of education has altered, so that 'through compliance with centrally imposed changes in pedagogy, teachers' experiences have led them to change some of their professional values concerning desirable pedagogy' (Webb \& Vulliamy, 2007, p. 561). The 'delivery delusion' is widespread, and many policy changes have narrowed the role of teacher to that of deliverer, with associated reduction of their pastoral roles and connections. Teachers in England felt a growing tension between the requirements of government and the needs of their pupils. The demand for 'performance' emphasised the managerially 'effective', while ignoring teachers' deeply rooted commitment to the affective aspects of teaching and learning (McNess, Broadfoot, \& Osborn, 2003; see also Dainton, 2005). The impact on teachers' professional associations has been marked. Whereas, in the 1980s, teachers would attend a NAPCE regional conference in their hundreds on a Saturday, there are now no regional activities.

Government claims that 'standards are rising' are challenged by those close to the research evidence (Tymms, 2004). So we are left with a situation where the use of narrow 'performance measures' to indicate the quality of schooling leads many participants into strategic behaviour, positioning themselves to 'look good' rather than to achieve important goals. There are many connected distortions in such education systems (Nichols \& Berliner, 2005). The distortion of whole systems as a result of using indicators as goals is well known in economics (Goodhart's law) and social sciences (Campbell's law), but there seems less widespread awareness in education. The actual effect on patterns of performance is to enhance the advantage that certain groups have always had in the education system, so that in the measured attainments at 16 years the social class gap has increased, the ethnicity gap has increased, and the gender gap has increased (Demack, Drew, \& Grimsley, 2000).

How to better the distortions

Here I offer a collection of elements which inform my practice in current times. They clearly do not address or answer the 'big-picture' questions which are implied above, as they are not a formula for social change on the large scale, but they do offer some thoughts for teachers and others to continue doing good work in a climate of performativity. Indeed, one of the elements I have learned is not to invest my time in the popular pastime of 'government-gazing'. I see too many examples large and small that convince me it is a waste of time. The most recent example refers to 'personalised learning' - I have now asked hundreds of teachers about the occasions when they have seen or heard this term (most of them have), and whether on these occasions the meaning of the term was clear. Not one person found a clear meaning. This I take as a good reason not to spend time searching further in government pronouncements, and a good opportunity to make the term reflect what the profession knows best (Watkins, 2007).

The elements which follow are presented in what may seem like a logical order, but I have not discovered them so neatly: it is more as though they have been pieced together over recent years. In the process, I am now struck that there are few guidelines for a profession oppressed, as there are for learners oppressed (Freire, 1970), and there are emanating from personal change in situations of oppression. From even the worst human situations, we are reminded that 'alongside each history of violence and oppression, there runs a parallel history of prudent, creative, and determined resistance' (Wade, 1997, p. 23).

The first issue is the climate of compliance. Teachers may say to their pupils 'Do your best', but then they, as teachers, do as they are told. So a necessary element entails recognising that compliance is not good enough. Effective schools are not compliant places (Rosenholtz, 1991). In classrooms, too, when teachers define positive student behaviour as interpersonal helpfulness, concern and understanding, students' interpersonal behaviour is more helpful than when diligence, compliance and respect for authority are emphasised (Benninga et al., 1991). 
An alternative to compliance is to be found by learning from our best experiences. This is one of the key principles in 'appreciative inquiry':

People have more confidence and comfort to journey to the future (the unknown) when they carry forward parts of the past (the known).

If we carry parts of the past forward, they should be what is best about the past.

(Hammond, 2000)

In practical terms, appreciative inquiries help to identify occasions when events went well, how they managed to be created, and what can be taken forward from them. One possibility for appreciative inquiry is to illuminate the occasions when teachers do not take up the many invitations to compliance which surround them. The best of these occasions can highlight narratives of principle. The resources teachers call on from their professional history, heritage and family speak eloquently of personal integrity and community value. This is not a matter of 'happy clappy talk', but requires fine detail to 'engage persons in a conversation concerning the details and implications of their own resistance. Through this process, persons begin to experience themselves as stronger, more insightful, and more capable of responding effectively to the difficulties' (Wade, 1997, p. 24).

I am not advocating open defiance: to do so would under-estimate the crucial role which is played by the fear that now inhabits the professional lives of teachers. Fear is designed to threaten negative consequences (more inspections, public shame, etc.) so that the public voice of resistance is effectively silenced. Open defiance is the least common form of resistance (Scott, 1990). Strategic defiance is more common, and reflects the Ethiopian proverb, 'When the great lord passes by, the wise peasant bows deeply and silently farts.'

The next element is to unpick the obsession with 'results', especially those which are derived from a most narrow form of testing that is fundamentally unreliable (Black, 2005). This is a very artificial form of achievement, and the rhetoric which claims that performance on such measures has strong links with later life chances wears thin. Unless young people have a positive story of themselves and their futures, they will not be motivated to perform well in any school-based tests. So rather than add more test-focused strategies (which usually turn out to be a case of 'more of the same'), we need to shift the focus to strategies which lead to improving performance in any area, and these involve improving learning and relationships. We have evidence that interventions such as the National Literacy Strategy serve to emphasise teacher-centred approaches, so that instead of promoting lifelong learners, we are at risk of producing lifelong addiction to teachers: 'A major shift away from teachers asking children about how they might do their work compared with pre-NLS levels, suggests that literacy hour teaching is more likely to engender learned helplessness than independent learning' (Hargreaves et al., 2003, p. 218).

There is no end point without a journey, so whatever performances young people exhibit as a result of their schooling, it is the journey of learning which is crucial to achieving any 'result'. For those who focus only on end points, the evidence is that a focus on performance can depress performance: learners end up with negative ideas about their competence, they seek help less, use fewer strategies, and become organised by the very judgements which do them down. And the evidence is that a focus on learning can enhance performance (Watkins, 2001).

A focus on learning can combat depersonalisation, if it is handled in a way which affirms the human disposition to relate experiences to each other in a storied form. Developing a true 'learning literacy' is a pressing twenty-first-century project. By contrast, a focus on learning which uses a category-based form, such as 'learning styles', will soon end up in bureaucratic practices (for example, teachers grouping students on the basis of some spurious questionnaire) rather than personal ones (for example, helping all learners to voice more detail about their experiences of learning and develop a more empowered narrative for themselves as a result). 
Once a focus on learning is developing, appreciative inquiry can be a powerful element once again, asking teachers to identify occasions when learning was at its best in a classroom, what led it to be so, how that situation occurred, and what we can derive from it. Having been through this process on many occasions with many teachers (and also pupils), the first three principles for promoting effective learning (Watkins, Carnell, \& Lodge, 2007) are reaffirmed: it is active, collaborative, and learner-driven. The fourth, learning about learning, emerges less strongly for understandable, historical reasons. This process also works against the demoralisation and depoliticisation of the profession, since it gives voice to teachers' submerged understandings and values, at the same time as emphasising that their local knowledge is much more salient than the prescriptions from afar. It helps to create a climate in which teachers can steer clear of the common collusion with hierarchical forms of power and control (Watkins, 2006).

An interesting development which happens alongside a focus on learning, but only if the stance on learning is authentically human, is an increasing focus on relationships. This may begin with consideration of collaborative learning in classrooms, but has spread, more quickly than I would have predicted, to considering the classroom as a learning community (Watkins, 2005). In Hong Kong, the government bought that book for every school and refer to it in all their curriculum guidelines. I understand this as a development which works against the fragmentation and separation which too often characterise learners' experiences and teachers' organisational lives, and represents the important layer around the classroom, where we need to move beyond the factory mentality of schooling and reclaim community in school (Watkins, 2004).

To conclude, I do not want to deny that my vision and the best practice of pastoral care and personal-social education have been destabilised, dissipated, fragmented and deprioritised in favour of a deprofessionalisation of teachers and an absurd focus on delivery and performance in most narrow terms. Notwithstanding this state of affairs, the questions of two decades ago (Watkins, 1985) and the frameworks for good practice (Watkins, 1992) strike me as still pertinent now. In the last two decades, I would prefer not to have needed to invest quite so much thought on how to contribute in this changed climate, but both my current focus and the processes I employ are a positive outgrowth which continues to reflect human values that are important to me. I manage the experience of efficacy combined with frustration. Nevertheless, in the changed context, I am left with unanswered questions, especially one: whose interests have been served by the changes to education in the last two decades?

References

Benninga, J.S., Tracz, S.M., Sparks, R.K., Solomon, D., Battistich, V., Delucchi, K.L., et al. (1991). Effects of two contrasting school task and incentive structures on children's social development. Elementary School Journal, 92, 149-167.

Black, P. (2005). The reliability of assessments. In J. Gardner (Ed.), Assessment and learning: Theory, policy and practice. London: Sage.

Dainton, S. (2005). Reclaiming teachers' voices. Forum, 47(2/3), 159-167.

Demack, S., Drew, D., \& Grimsley, M. (2000). Minding the gap: Ethnic, gender and social class differences in attainment at 16, 1988-95. Race Ethnicity and Education, 3, 117-143.

Department of Education and Science (1978). Curriculum 11-16: Working papers by HM Inspectorate. London: HMSO.

Freire, P. (1970). Pedagogy of the oppressed. London: Penguin.

Gardner, P. (1998). Classroom teachers and educational change 1876-1996. Journal of Education for Teaching, 24, 33-49.

General Teaching Council for England (GTCE) (2003). Teachers on teaching: A survey of the teaching profession. London: GTCE/Guardian/MORI.

Habermas, J. (1975). Legitimation crisis. Boston: Beacon Press. 
Hammond, S.A. (2000). The thin book of appreciative inquiry. Bend, OR: Thin Book Publishing.

Hargreaves, L., Moyles, J., Merry, R., Paterson, F., Pell, A., \& Esarte-Sarries, V. (2003). How do primary school teachers define and implement 'interactive teaching' in the National Literacy Strategy in England? Research Papers in Education, 18, 217-236. Jenkins, E.W. (2000). The impact of the National Curriculum on secondary school science teaching in England and Wales. International Journal of Science Education, 22(3), 325-336.

Leadbeater, C. (2004). Personalisation through participation: A new script for public services. London: Demos.

Lewin, K., Lippitt, R., \& White, R. (1939). Patterns of aggressive behavior in experimentally created 'social climates'. Journal of Social Psychology, 10, 271-299.

McCowan, T. (2006). Approaching the political in citizenship education: The perspectives of Paulo Freire and Bernard Crick. Educate, 6(1), 57-70.

McLaughlin, M. W. (1991). Test-based accountability as a reform strategy. Phi Delta Kappan, 73(3), 248-251.

McNess, E., Broadfoot, P., \& Osborn, M. (2003). Is the effective compromising the affective? British Educational Research Journal, 29(2), 243-257.

Nichols, S.L., \& Berliner, D.C. (2005). The inevitable corruption of indicators and educators through high-stakes testing. Tempe, AZ: Arizona State University Education Policy Studies Laboratory.

Ohanian, S. (1999). One size fits few: The folly of educational standards. Portsmouth, NH: Heinemann.

Reay, D., \& Wiliam, D. (1999). 'I'll be a nothing': Structure, agency and the construction of identity through assessment. British Educational Research Journal, 25(3), 343-354.

Rosenholtz, S.J. (1991). Teachers' workplace: The social organization of schools. New York: Teachers College Press.

School Curriculum and Assessment Authority (SCAA) (1996). National Forum for Values in Education and the Community. Consultation on values in education and the community: Spiritual and moral development. COM/96/608. London: SCAA.

Scott, J.C. (1990). Domination and the arts of resistance. New Haven, CT: Yale University Press.

Stradling, R. (1981). Political education: Developments in Britain. In D. Heater \& J. Gillespie (Eds.), Political education in flux. London: Sage.

Tymms, P. (2004). Are standards rising in English primary schools? British Educational Research Journal, 30(4), 477-494.

Wade, A. (1997). Small acts of living: Everyday resistance to violence and other forms of oppression. Contemporary Family Therapy, 19(1), 23-39.

Watkins, C. (1985). Does pastoral care = personal and social education? Pastoral Care in Education, 3(3), 179-183.

Watkins, C. (1992). Whole school personal-social education: Policy and practice.

Coventry: National Association for Pastoral Care in Education.

Watkins, C. (2001). Learning about learning enhances performance. London: Institute of Education School Improvement Network (Research Matters series no. 13).

Watkins, C. (2004). Reclaiming pastoral care. Pastoral Care in Education, 22(2), 3-6.

Watkins, C. (2005). Classrooms as learning communities: What's in it for schools?

London: Routledge.

Watkins, C. (2006). When teachers reclaim learning. Forum for Promoting 3-19

Comprehensive Education, 48(2), 121-129.

Watkins, C. (2007). Personalised classroom learning. London: Institute of Education International Network for School Improvement (Research Matters series no. 29).

Watkins, C., Carnell, E., \& Lodge, C. (2007). Effective learning in classrooms. London:

Paul Chapman/ Sage.

Webb, R., \& Vulliamy, G. (2007). Changing classroom practice at Key Stage 2: The impact of New Labour's national strategies. Oxford Review of Education, 33(5), 561-580. 
